\title{
МЕТОДИЧНІ ПІДХОДИ ДО ОЦІНКИ ФУНКЦІОНУВАННЯ АГРОПРОДОВОЛЬЧИХ ЛАНЦЮГІВ
}

\author{
Білоцерківський національний аграрний \\ університет, \\ Міністерство освіти і науки України, \\ кафедра обліку і оподаткування, \\ пл. Соборна, 8/1, м. Біла Церква, \\ 09100, Україна, \\ тел.: 0456331128 , \\ e-mail:buxoblik@ukr.net
}

\begin{abstract}
Анотація. Стаття присвячена обгрунтуванню методичного інструментарію дослідження результативності агропродовольчих ланцюгів.

Метою статті $\epsilon$ узагальнення існуючих методичних підходів до оцінювання результативності агропродовольчих ланцюгів, обгрунтування алгоритму визначення доданої вартості на мікро- та макрорівнях та складових інформаційного забезпечення.

Використано наступні методи дослідження:монографічний; теоретичного узагальнення;методи пізнання, діалектичний метод, аналіз та синтез, індукція та дедукція, системний комплексний підхід.

Доведено, що методологічною основою для розрахунку показників доданої вартості глобальних агропродовольчих ланцюгів є система обліку міжнародної торгівлі на основі доданої вартості Trade in Value Added та таблиці «Затрати-Випуск», які поєднані національними таблицями «Затрати-Випуск». Аргументовано, що ускладненим є розрахунок величини доданої вартості національного походження, яка включена у проміжних затратах експортованої продукції.

Обгрунтовано досліджувати напрями формування доданої вартості агропродовольчих ланцюгів за напрямами: галузями в системі національних рахунків; за видами економічної діяльністю; на рівні суб'єктів господарювання. Доведено, що розрахунок доданої вартості при дослідження агропродовольчих ланцюгів доцільно проводити на рівні кожного учасника (актора) 3 метою реалізації принципів вартісно-орієнтованого управління та суцільне визначення величини цього показника на рівні суб’єктів господарювання.

Аргументовано, що з метою нівелювання розбіжностей у величині показника доданої вартості на мікро- та макрорівнях необхідно гармонізувати бухгалтерську звітність економічних суб'єктів до вимог СНР та передбачити виділення показника доданої вартості окремим рядком.
\end{abstract}

Ключові слова: додана вартість, агропродовольчі ланцюги, методика, інформаційне забезпечення.

\section{METHODOLOGICAL APPROACHES TO THE ASSESSMENT OF FUNCTIONING OF AGRICULTURAL CHAINS}

Bila Tserkva National Agrarian University, Ministry of Education and Science of Ukraine, Department of Accounting and Taxation, pl. Soborna, 8/1, Bila Tserkva, 09100, Ukraine, tel.: 04563 31128, e-mail: buxoblik@ukr.net 
Актуальні проблеми розвитку економіки регіону. Вип 16. T.2

Abstract. The article is devoted to substantiation of methodical tools of research of efficiency of agro-food chains. The aim of the article is to generalize the existing methodological approaches to evaluating the effectiveness of agri-food chains, substantiation of the algorithm for determining value added at the micro and macro levels and components of information support. The following research methods were used: monographic; theoretical generalization, methods of cognition, dialectical method, analysis and synthesis, induction and deduction, systemic integrated approach. It is proved that the methodological basis for calculating the value added of global agri-food chains is the system of accounting for international trade based on value added Trade in Value Added and tables "CostsOutput", which are combined with national tables "Costs-Output". It is argued that it is difficult to calculate the value added of national origin, which is included in the intermediate costs of exported products. It is reasonable to study the directions of formation of value added of agro-food chains in the following directions: branches in the system of national accounts; by types of economic activity; at the level of business entities. It is proved that the calculation of value added in the study of agri-food chains should be carried out at the level of each participant (actor) in order to implement the principles of cost-oriented management and continuous determination of the value of this indicator at the level of economic entities. It is argued that in order to eliminate differences in the value of value added at the micro and macro levels, it is necessary to harmonize the financial statements of economic entities to the requirements of the SNA and provide for the allocation of value added on a separate line.

Key words: added value, agro-food chains, methods, information support.

Вступ. Розвиток економічних відносин у агропродовольчих ланцюгах спрямовані на інтеграцію, кооперацію, уніфікацію та стандартизацію обліково-податкового процесу аграрного сектору, які набувають особливої актуальності в сучасних умовах розвитку України. Важливою економічною категорією результативності функціонування ланцюга виступає додана вартість, формування якої на мікрорівні повинно базуватися на принципах сучасного рахівництва, закріплених у міжнародних стандартах фінансової звітності, а на макрорівні - на принципах системи національних рахунків (СНР).

Виходячи з існуючої фінансової концепції, показник доданої вартості містить в собі величину валового доходу для оплати факторів виробництва, зазначених Д. Кейнсом: дохід на вкладений капітал - прибуток, який розподіляється власникам (дивіденди), державі (податок на прибуток), у фонди накопичення і споживання, на амортизацію (фінансовий ресурс, звільнений від податків і накопичується для відновлення основних фондів), у дохід власника землі (земельна рента); в дохід найманих працівників і підприємця (оплата праці), на частину доходу, передається підприємцем на соціальні потреби (відрахування на соціальні потреби), на непрямі податки в складі ринкової ціни[1].

Під доданою вартістю господарюючого суб'єкта слід розуміти грошовий вираз знову створеної живою працею працівників вартості випуску продукції, яка визначається як перевищення виручки від реалізації над спожитими на виробництво і реалізацію матеріальними ресурсами і послугами сторонніх організацій.

Розглядаючи специфіку функціонування агропродовольчих ланцюгів за критерієм територіального охвату, то можна виділити наступні глобальні ланцюги та локальні, які формують різні величини доданої вартості, що відповідно вимагає обгрунтування методичних підходів до іiі розрахунку та відповідного інформаційної бази цього аналізу. Так, в економічній літературі на даний момент практично відсутні праці, які б досліджували міжнародну торгівлю у рамках концепції глобальних виробничоторгових ланцюгів, тобто в термінах доданої вартості. Окрім цього, на національному рівні спостерігається розпорошеність методичних підходів та відсутності універсальної методики, який би дозволив достовірно визначити об'єктивно величину доданої вартості на рівні локальних ланцюгів та нарівні кожного його учасника. 
Актуальні проблеми розвитку економіки регіону. Вип 16. T.2

Постановка завдання. Основною метою статті $\epsilon$ узагальнення існуючих методичних підходів до оцінювання результативності агропродовольчих ланцюгів, обгрунтування алгоритму визначення доданої вартості на мікро- та макрорівнях та напрямів удосконалення інформаційного забезпечення аналітичного процесу. Для досягнення поставленої мети було визначено такі завдання:

аналіз методичних підходів до визначеннярезультативності агропродовольчих ланцюгів на макро- та макрорівнях;

розробка алгоритму дослідження формування доданої вартості у агропродовольчих ланцюгах;

вивчення складових інформаційного забезпечення процесу дослідження результативності агропродовольчих ланцюгів та розробка напрямів його удосконалення.

3 метою досягнення поставлених завдань використано відповідну систему методів дослідження: монографічний - при формулюванні мети та висновків дослідження, результати якого знайшли відображення в статті. Метод теоретичного узагальнення зарубіжних та вітчизняних науковців використано при здійсненні критичного аналізу існуючих методичних підходів до оцінювання агропродовольчих ланцюгів на макро- та макрорівнях. При обгрунтуванні заходів щодо удосконалення процесу вивчення результативності агропродовольчих ланцюгів та узагальненні висновків використано загальнонаукові методи пізнання, такі як діалектичний метод, аналіз та синтез, індукція та дедукція, системний комплексний підхід.

При проведенні дослідження результативності функціонування агропродовольчих ланцюгів додержувалися засад концепції вартості ланцюга, який передбачає урахування діяльності усіх його акторів (учасників) по доведенню агропродовольства від виробника до кінцевого споживача.

Результати. Відомо, що доходи від експорту товарів та послуг оцінюються показниками валового та чистого експорту, які представлено у платіжному балансі та в системі національних рахунків. Водночас,показник валового експорту не враховує величину проміжного споживання товарів та послуг, які припадають на одиницю доданої виручки. Зазначимо, що при розрахунку показника чистого експорту як різниці між обсягом експорту та імпорту агропродовольства певної галузі також не враховуються міжгалузеві зв'язки, що не дозволяє ув'язати експорт із проміжним споживанням ввезеної продукції по імпорту у інших галузях. Оцінка внеску кожної галузі в експортні доходи економіки на основі розглянутих показників буде викривленою, оскільки галузі характеризуються різними параметрами частки проміжного імпорту у валовому випуску. Якщо розглянути різні види продукції, які відрізняються за структурою доданої вартості - одні, які виробляються із імпортованої сировини, доходи формуються за рахунок великих обсягів експорту та імпорту; інші включають додану вартість, стоврену не лише до прикладу харчовою промисловістю, але й в сільському господарстві, а також інших суміжних галузях, які входять у виробничий ланцюг. Отже, величина приросту обсягів експорту агропродовольства порізному впливає на економічне зростання - збільшення експорту продуктів харчування, на перший погляд, повинно стимулювати економічний ріст за рахунок збільшення випуску проміжних продуктів. Однак, величина доданої вартості, створеної у розрахунку на одиницю експортної виручки всередині усієї виробничого ланцюга, відіграє важливу роль у розумінні взаємозв'язку експорту та економічного росту.

Очевидно, що в глобальних виробничих ланцюгах національні економіки фактично торгують не товарами та послугами, а доданою вартістю, яка в них включена. Узагальнення наукової літератури дозволила встановити, що перші результати оцінки міжнародної торгівлі доданою вартістю та основи методології іiї статистичного обліку 
були опубліковані у другій половині 1990-х років, а з 2011 р. - міжнародні організації (ЮНКТАД, Свростат, ОЕСР, СОТ) запустили онлайн-сервіси із відкритим доступом до баз даних, у яких створювана та спожита у світі додана вартість поділена за країнами та галузями[2].

Розроблені методології базуються на взаємопов’язаних таблицях «ЗатратиВипуск» для кожної країни та передбачає використання показників, які характеризують ступінь інтеграції країни у глобальні ланцюги вартості на основі співвідношення власної та імпортованої доданої вартості у валовому експорті та кінцевому попиті. Однак, методологія не використовує дані про результати діяльності реальних ланцюгів, а використовує агреговані галузеві показники, а на сьогодні існує необхідність у проведенні макроекономічному аналізі показника «додана вартість» національного походження в експорті.

Методологічною основою для розрахунку показників доданої вартості, які створені в межах країні, може стати система обліку міжнародної торгівлі на основі доданої вартості Trade in Value Added - TiVA, яка є спільною ініціативою ОЕСР и СОТ, дозволяє налагодити моніторинг ії створення та руху цього показника у розрізі країн та галузей в системі міжнародного поділу праці. Сутність методології обліку міжнародної торгівлі на основі доданої вартості TiVA полягає у створенні глобальних таблиць «Затрати-Випуск» шляхом поєднання національних таблиць «Затрати-Випуск» із потоками двосторонньої торгівлі $[3,4]$. Однак, дана база включає лише 61 країну світу, на які припадає 95\% світового ВВП. Із колишніх радянських країн до неї включено три країни Балтики, Росія, а Україну до неї не включено. Однак, унаслідок актуальності досліджень по вивченню глобальних ланцюгів створення та руху вартості на сьогодні ведеться робота 3 формування подібних баз статистичного аналізу, що дозволить визначити на рівні країні їі залучення у процес міжнародного поділу праці, який можна оцінити на основі показника частки проміжного імпорту в експорті, який зазвичай $є$ вищим для малих відкритих економік та має тенденцію до росту.

Методологія TiVA постійно удосконалюється, останні зміни у переліку та методики розрахунку окремих показників були внесені у 2015 р. відповідно до другої версії даного інструментарію [5]. Урахування внесених змін, а також раніше діючу систему показників, можна виділити наступні TiVA індикатори: 1. Індикатори участі країни в глобальних ланцюгах вартості - індикатори вперед ідущей інтеграції в глобальному ланцюзі (Forwardparticipation), індикатори зворотної інтеграції (Backwardpacipation); 2. Індикатори походження доданої вартості у валовому експорті у кінцевому попиті (ValueAddedinFinalDemand); 3. Індикатори вітчизняної доданої вартостів національному експорті. Основним показником TiVA, який є важливим для оцінки величини показника доданої вартості національного походження в експорті та характеризує ступінь інтеграції економіки в глобальні ланцюги. На величину вартості національного походження в експорті впливає не лише додана вартість галузі, але також ступінь іiі інтегрованості із іншими галузями економіки, частка вітчизняних ресурсів, що використовується цією галуззю у проміжному споживанні. Ускладненим $\epsilon$ розрахунок складової, що характеризує додану вартість національного походження, яка включена у проміжних затратах експортованої продукції. Очевидно, що частка доданої вартості кожного виду економічної діяльності в експорті є вищою, у випадку більшої валової доданої вартості у кожній експортно-орієнтованій галузі, і чим більше вітчизняних ресурсів використовується у проміжному споживанні. Зазначимо, що на величину цього показника впливають також наступні фактори: зміна цін імпорту сировини та експорту продуктів іiі переробки; зміна обсягів імпорту сировини та експорту продуктів його переробки. 
Актуальні проблеми розвитку економіки регіону. Вип 16. T.2

Щоб зробити обгрунтовані висновки, необхідно дослідити галузеву структуру експорту та доданої вартості в експорті для української економіки. Розрахунок показника «додана вартість національного походження в експорті» дозволяє вирішити важливе завдання у напрямі пошуку можливостей збалансованого економічного росту: поділити вироблений ВВП на дві частини - додану вартість, створену за рахунок експорту, а також додану вартість, створену за рахунок внутрішнього попиту. На основі цього можна здійснити обгрунтування шляхів економічного зростання, які не будуть зумовлювати торгові дисбаланси.

Так, традиційна менш складна агропродовольча продукція виступає «інгратором» вітчизняних ланцюгів поставок. Пряма додана вартість, може бути не високою, однак за рахунок використання галуззю переважно вітчизняної сільськогосподарської продукції досягається висока додана вартість усього виробничого ланцюга. Встановлено, що у вітчизняній практиці дослідження питань створення доданої вартості можна виділити наступні напрями: додана вартість визначається на основі в цілому по галузях в системі національних рахунків;додана вартість визначається в цілому по видах економічної діяльністю на основі суцільного обстеження суб'єктів господарювання органами Державної служби статистики України; додана вартість розрахована на рівні підприємства, як база оподаткування податком на додану вартість (рис.1).

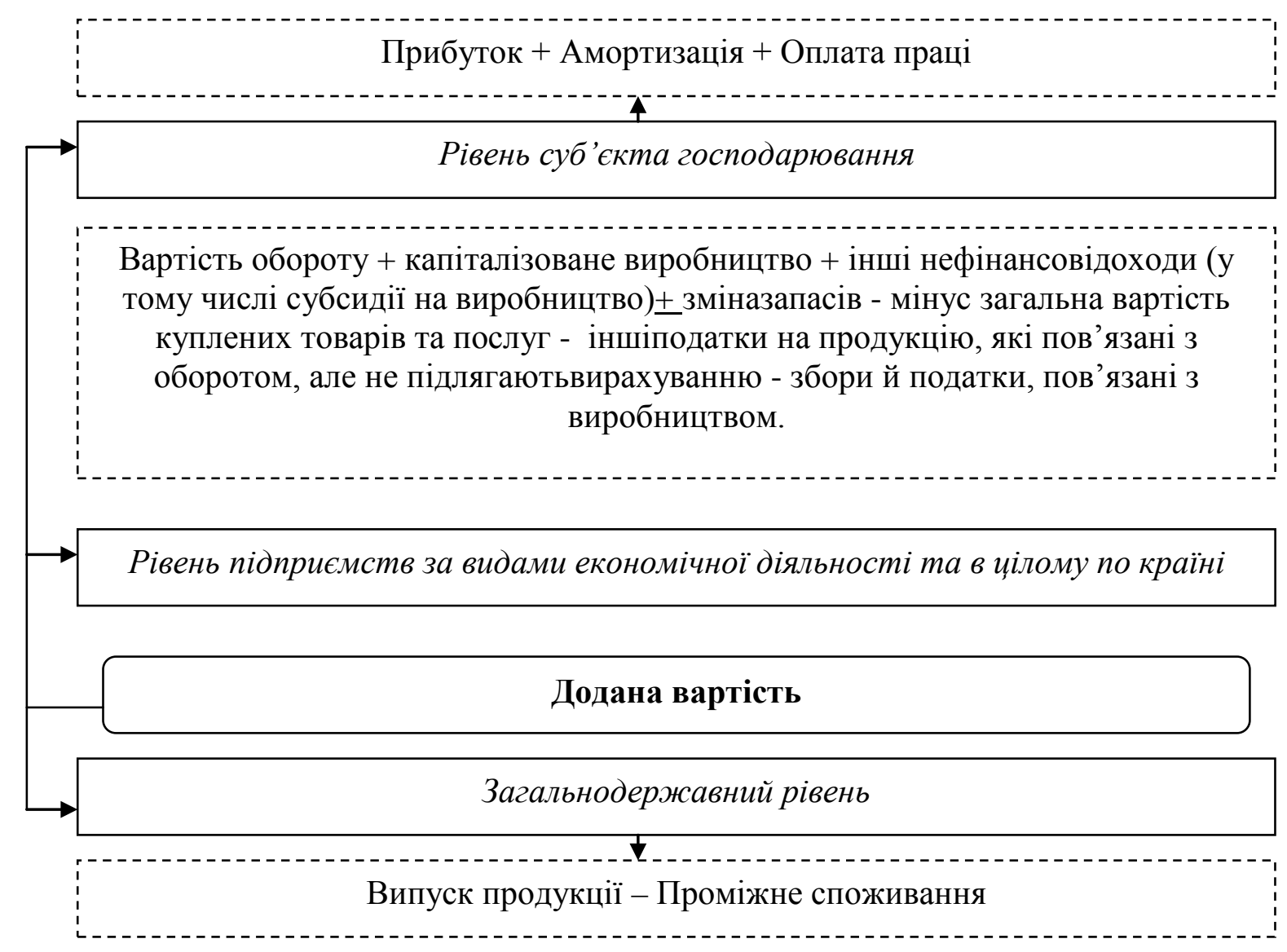

Puc. 1. Алгоритм визначення доданої вартості на мікро- та макрорівнях Джерело: узагальнено автором.

Fig. 1. Algorithm for determining value added at the micro and macro levels

Враховуючи відсутність в Плані рахунків бухгалтерського обліку активів, капіталу, зобов'язань і господарських операцій підприємств і організацій відображають 
рахунків призначених для обліку доданої вартості можливе лише здійснювати розрахунковим способом використовуючи дані фінансової звітності суб'єктів господарювання.

Основними джерелами інформації визначення величини доданої вартості на рівні підприємства $є$ фінансовий облік, який не забезпечує користувачів всіх рівнів оперативною інформацією. Такі функції виконує управлінський облік, що виступає основою інформаційного забезпечення прийняття раціональних управлінських рішень.

Оскільки предметом дослідження є функціонування агропродовольчих ланцюгів та створення ними величини доданої вартості, то розглянемо складові методичного та інформаціно-аналітичного забезпечення на макрорівні. Відомо, що центральне місце в системі показників макроекономічного обліку i аналізу займає ВВП, який тісно пов'язаний із показником доданої вартості. Всі суб'єкти господарювання, незалежно від виду економічної діяльності i сфери виробництва (матеріального чи нематеріального), виробляють додану вартість. Сума всієї виробленої в економіці валової доданої вартості й становить величину ВВП. У свою чергу валова додана вартість (ВДВ) обчислюється як різниця між випуском і проміжним споживанням. При цьому під випуском в системі національних рахунків (СНР) розуміється сумарна вартість товарів (незалежно від їх використання) та послуг, що $є$ результатом економічної діяльності резидентів у звітному періоді [6]. 3 метою розрахунку доданої вартості під випуском розуміється сума реалізованої продукції (послуг), приросту незавершеного виробництва, а також готової і відвантаженої продукції. Тобто показник доданої вартості не диференційований з точки зору стадій кругообігу капіталу. Це перша 3 істотних методологічних особливостей у трактуванні доданої вартості в національному рахівництві.

У свою чергу, проміжне споживання - це вартість товарів i послуг, які споживаються в звітному періоді в процесі виробництва товарів та послуг. Відповідно до методології СНР проміжне споживання включає матеріальні витрати, оплату нематеріальних послуг (у тому числі послуг фінансового посередництва), витрати на відрядження у частині оплати проїзду до місця службового відрядження і назад та витрати по найму житлового приміщення, оплату разових робіт, виконуваних працівниками, які не перебувають у штаті організації[7].У даному документі розкривається друга особливість - включення оплати послуг фінансового посередництва (у т.ч. відсотків за користування позиковим фінансовим капіталом) до складу проміжного споживання. Вважаємо, що такий підхід є цілком обгрунтованим, оскільки фінансове посередництво в національному рахівництві розцінюється як нематеріальні послуги, оплату за які передбачено відносити до проміжного споживання. Однак, якщо подивитися на послуги фінансового посередництва (в частині надання бізнесу банківських кредитів) з позиції прямої участі позикового капіталу у створенні доданої вартості, то при іiі розрахунку для цілей управління доцільно включати плату за користування цим капіталом до складу доданої вартості, оскільки для керівництва компанії важливо мати інформацію про те, яка загальна величина доданої вартості, а також про те, яка іï частина створена тільки за рахунок обороту капіталу власника, а яка - виключно за рахунок обороту позикового капіталу.

Третьою методологічної особливістю розрахунку показників економічного обороту в СНР $є$ те, що амортизація основних засобів і нематеріальних активів (споживання основного капіталу) не входить в проміжне споживання. Тому ВВП і ВДВ мають відповідно визначення «валовий» і «валова», які означають те, що до складу цих показників входить величина споживання основного капіталу.У трактуванні ж показників «додана вартість» i «проміжне споживання» 3 точки зору класичної економічної теорії амортизація є елементом останнього.І це цілком виправдано, 
оскільки з точки зору кругообігу капіталу амортизація є не що інше, як споживання в даному операційному циклі частини матеріалізованої (у вигляді об'єктів основних засобів і нематеріальних активів) результату минулого праці. I для оцінки результатів бізнесу в звітному періоді більш об'єктивним $\epsilon$ показник доданої вартості без урахування величини споживання основного капіталу, у вигляді амортизаційних відрахувань. I для оцінки результатів бізнесу в звітному періоді більш об'єктивним $є$ показник доданої вартості без урахування величини споживання основного капіталу, у вигляді амортизаційних відрахувань. За такого підходу досліджуваний показник відображає реальну величину нової вартості, створеної бізнесом, отже, більш інформативним для аналізу та управління діяльністю суб'єкта господарювання.

Четверта концептуальна особливість трактування категорії «додана вартість» у національному рахівництві полягає в тому, що він ототожнює додану вартість лише 3 доходом, створеним конкретним видом економічної діяльності в загальному обсязі ВВП, тоді як на рівні підприємства доцільно вивчати показник доданої вартості не тільки 3 позиції фінансового результату бізнесу в цілому, але i 3 точки зору матеріального носія цієї величини, тобто конкретного продукту.

П'ятою суттєвою методологічною особливістю полягає в тому, що СНР розрізняє наступні види доходу для реального сектору економіки: додану вартість (вироблений дохід); сальдо первинних доходів від виробництва і власності; вторинні доходи (безоплатні асигнування з боку); чистий дохід (залишковий дохід після всіх нарахувань до виплат). Тобто в макроекономічному обліку додана вартість є дохід, отриманий від процесу виробництва. Якщо ж абстрагуватися від виробничого підходу до сутності досліджуваного показника та сконцентруватися на природі капіталу як вартості, що генерує в процесі господарського кругообігу нову (додану) вартість, то можна зробити висновок про те, що додана вартість створюється як у поточному (виробничому) бізнеспроцесі (в цьому випадку іiї носієм виступає конкретний продукт, робота або послуга), так і в неосновному (не пов'язане з поточною діяльністю) бізнес-процесі (в цьому випадку додана вартість втілена в прибутку від цієї діяльності і витратах, пов'язаних із утриманням персоналу, зайнятого в ній, при цьому матеріальний носій цієї частини доданої вартості виділити не завжди можливо, вона повинна розглядатися 3 прагматичної точки зору як додаткове джерело задоволення фінансових інтересів учасників всього бізнес-процесу). Отже, додана вартість трактується як показник, що характеризує результат функціонування економічної системи на мікро- і макрорівні.

Показник доданої вартості має двоїсту природу: по-перше, він характеризує внесок даного бізнесу в ВВП країни i, отже, ефективний бізнес матиме більш високі темпи зростання доданої вартості в порівнянні 3 темпами зростання обсягів виробництва; по-друге, він характеризує розподіл створеного бізнесом продукту між працівниками, власником і державою; з позиції власника ефективний той бізнес, у якого темпи зростання прибутку випереджають темпи зростання доданої вартості. Необхідно зазначити, про проблему тінізації економіки і їі відображення в системі національних рахунків. Сутність їі проблеми полягає не тільки у площині використання певних методів оцінювання обсягів тіньової діяльності, але й у виборі критеріїв відношення економічної діяльності до тіньового сектору та їх гармонізацією 3 методологічною та законодавчою базою різних країн світу, доцільності включення незаконної діяльності в оцінки макропоказників та у формі відображення цих обсягів у системі національного рахівництва. Тому, на нашу думку, процес розвитку теоретикометодологічного забезпечення статистичного оцінювання тіньового сектору економіки у рамках СНР є незавершеним та потребує проведення додаткових досліджень з метою подальшого удосконалення його концептуальних основ. 
Актуальні проблеми розвитку економіки регіону. Вип 16. T.2

Методика розрахунку валової доданої вартості детально роглянута в Методологічних положеннях Держстату і спільних виданнях Євростату з МВФ, Організацією економічного співробітництва та розвитку (ОЕСР), ООН та Світового банку. Міжнародна стандартна галузева класифікація всіх видів економічної діяльності визначає валову додану вартість (від англ. Gross Value Addet. GVA) як різницю між вартістю випуску продукції в основних цінах і вартістю проміжного споживання. Водночас, Державна служба статистики України описує валову доданої вартості як різницю між випуском і проміжним споживанням; вона містить у собі первинні доходи, що створюються учасниками виробництва і розподіляються між ними. При цьому показник валової доданої вартості за видами економічної діяльності розраховується як сума оплати праці найманих працівників, інших податків за виключенням інших субсидій, пов'язаних з виробництвом, та валового прибутку (змішаного доходу) [8].

Зазначимо, термін «валова» означає, що до складу доданої вартості входить величина споживання основного капіталу. У трактуванні показників «додана вартість» і «проміжне споживання» в контексті класичної економічної теорії амортизація $\epsilon$ елементом останнього.Питання включення амортизації необоротних активів до складу ДВ є дискусійним і визначає різні методики іï розрахунку. За статистичного підходу СНР ототожнює валову ДВ тільки 3 доходом, створеним певним видом економічної діяльності в загальному обсязі ВВП.

У системі національного рахівництва додана вартість використовується для розрахунку величини ВНП, який становить собою суму доданої вартості всіх фірм виробників, галузей і відображає лише капіталізовану економічною системою матеріальну частину продукування доданої вартості, яка тлумачиться обмежено, визначаючи, що ії продуцентами можуть бути лише підприємства або працівники.

В Україні розрахунки щодо створення валової доданої вартості за інституційними секторами економіки здійснюються тільки 32004 р. За даними Державної служби статистики частка сектора фінансових корпорацій у створенні валової доданої вартості у 2018 р. становила близько 1 \%, що значно нижче, ніж у країнах СС. Отже, незважаючи на значний розвиток сектора фінансових корпорацій за останні роки, він залишається тим основним компонентом, якого не вистачає для прискорення економічного зростання в Україні.

У національних рахунках використовуються два рівні показників і два методи оцінки. Для економіки в цілому результати вимірюються випуском товарів і послуг та валовим внутрішнім продуктом у ринкових цінах, для секторів і видів економічної діяльності - випуском в основних цінах і валовою доданою вартістю.

Випуск товарів та послуг визначається вартістю продукції, яка $\epsilon$ результатом виробничої діяльності господарюючих одиниць-резидентів у звітному періоді. До випуску включаються:усі товари, незалежно від їхнього використання (як товари, надані іншим одиницям, котрі їх не виробляють, так і товари вироблені для власного кінцевого споживання або нагромадження, включаючи приріст запасів матеріальних оборотних коштів у виробника);послуги, надані іншим інституційним одиницям, зокрема, неринкові послуги органів державного управління i некомерцінних організацій; побутові і домашні послуги (приготування їжі. прибирання, догляд за дітьми тощо), які налаються домашнім господарствам найманою домашньою прислугою;умовно-обчислена вартість проживання у власному житлі.

У системі національних рахунків розрізняють два типи випуску - ринковий i неринковий. Так, ринковий випуск здійснюється у секторі нефінансових корпорацій, фінансових корпорацій та секторі домашніх госполарств (крім виробництва товарів та послуг лля власного кінцевого використання і умовно обчисленої вартості послуг по проживанню у власному житлі). До ринкового випуску включають: товари і послуги, 
які реалізуються за економічно значущими цінами; товари і послуги, які обмінюються за бартером на інші товари, послуги або активи; товари і послуги, які налаються роботодавцями своїм робітникам як оплата праці в натуральній формі; товари i послуги, які виробляються одним підрозділом (закладом) і поставляються іншому підрозділу (закладу) цього ж підприємства для використання у виробництві в цьому самому часі та наступних періодах; готову продукцію та незавершене виробництво, які надходять у запаси матеріальних оборотних коштів у виробника і призначені для ринкового використання, тобто на вказані вище цілі.

Неринковий випуск $€$ характерним для секторів загального державного управління, некомерційних організацій, що обслуговують домашні господарства та сектора домашніх господарств в частині виробництва товарів і послуг для власного кінцевого використання. Неринковий випуск включає:товари і послуги, які надаються безоплатно або за цінами, що не мають економічного значення, іншим інституційним одиницям;готову продукцію та незавершене виробництво, які призначені для неринкового використання і надходять у запаси матеріальних оборотних коштів у виробника;товари і послуги вироблені інституційними одиницями для їхнього власного кінцевого використання, тобто кінцевого споживання або валового нагромадження основного капіталу. Неринковий випуск оцінюється переважно за сумою поточних витрат на виробництво товарів та послуг.

Поточні витрати на виробництво включають матеріальні витрати, оплату послуг сторонніх організацій, оплату праці найманих працівників (включаючи фактичні та умовно обчислені внески роботодавців на соціальне страхування), інші податки (за виключенням субсидій) пов'язані 3 виробництвом, споживання основного капіталу[9].Для оцінки випуску товарів та послуг за видами економічної діяльності використовуються основні ціни. До їх складу не входять будь-які податки на продукти, але вони містять субсидії на них. Неринкова продукція оцінюється на основі поточних витрат (включаючи споживання основного капіталу), оскільки більшість із них не представлено на ринку, що не дає можливості використовувати ринкові цінові аналоги. Зазначимо, що ринкові ціни застосовуються для оцінки випуску товарів та послуг в цілому по економіці. Вони включають податки на продукти за виключенням субсидій на продукти.

За статистичною методологією випуск на рівні підприємств (обсяг виробленої продукції) обраховується в першу чергу за даними фінансової звітності підприємств. Для великих та середніх підприємств, що подають повну фінансову звітність, випуск розраховується як сума чистого доходу від реалізації товарів та послуг, інших операційних доходів та інших (нефінансових) доходів підприємства, до якої додають виробництво для власного інвестування та зміна запасів підприємства і віднімають субсидії на виробництво та витрати на покупку товарів для перепродажу. Для малих підприємств випуск дорівнює сукупним доходам підприємства із відповідними коригуваннями вищезазначеного показника на власне виробництво, запаси та товари для перепродажу. Водночас випуск у нефінансових корпорацій у СНР розраховується на основі показника реалізації товарів та послуг за структурною звітністю підприємств (форма №1-підприємництво) за вирахуванням чистих податків на продукти (що аналогічно чистому доходу від реалізації товарів та послуг у фінансовій звітності). До цього показника як і в структурній статистиці додають зміну запасів та продукцію для власних потреб та віднімають вартість товарів для перепродажу. Але на відміну від статистики підприємств від випуску віднімають також (розрахункові) прибутки від переоцінки запасів, а також торгову націнку за товарами для перепродажу.

Отже, величина показника випуску за статистичною звітністю підприємств $є$ вищою за значення випуск за СНР, оскільки він включає інші операційні та 
неопераційні доходи підприємства: зокрема доходи від курсових різниць, від операційної оренди активів; дохід від роялті, відсотків, отриманих на залишки коштів на поточних рахунках в банках, дохід від продажу активів (різниця між балансовою вартістю та ціною продажу), одержані штрафи, пені, неустойки тощо, відшкодування раніше списаних активів та від списання кредиторської заборгованості, а також прибутки від переоцінки запасів.Відмінності даних статистики підприємств та національних рахунків скоріш за все відображають значний обсяг розрахункових доходів у звітності підприємств, а аналогічні показники СС теж вказують на те, що значення показників структурної статистики підприємств та національних рахунків не обов'язково повинні бути однаковими. Окрім того, існування суттєвого обсягу недорахованого ВВП в Україні в структурній статистиці підприємств можливе неврахування обсягів тіньової економіки, яка відображається в системі національних рахунків. За попередніми розрахунками Мінекономрозвитку рівень тіньової економіки у 2018 році склав 30\% від обсягу офіційного ВВП, що на 2 в.п.1 менше за показник 2017 року і є найнижчим рівнем, починаючи з 2009 року.

Отже, додана вартість як економічна категорія за показниками рахунків бухгалтерського обліку має важливе значення в обгрунтуванні результатів господарської діяльності підприємства. Складові доданої вартості показують результативність господарювання, мотивацію власників, вартість робочої сили (найманих працівників), доходи держави і стан інвестиційно-інноваційної діяльності підприємства. Зважаючи на те, що складові доданої вартості на рахунках бухгалтерського обліку має методичні недоліки, то доцільно запропонувати наступні напрями удосконалення системи звітності про витрати і результати виробництва:зміна порядку групування інформації для іiі отримання в розрізі відповідних категорій системи національних рахунків, зокрема, визначення випуску продукції методом «витрати-випуск» та витрат на виробництво продукції за економічними елементами;застосування фінансової концепції звітності, що містить інформацію про залишки, виробництво, реалізації продукції, витрати на ії виробництво за економічними елементами та фінансові результати 3 метою оцінки фінансово-господарської діяльності підприємства і складання національних рахунків.

При наданні економічними суб'єктами бухгалтерської звітності, що відповідає вимогам СНР доцільно передбачити виділення показника доданої вартості окремим рядком, у результаті чого з'явиться можливість оцінити внесок конкретного суб'єкта в загальній сумі валового внутрішнього продукту. Така пропозиція вимагає передбачити удосконалення форм фінансової звітності підприємств.

Вважаємо, що розрахунок доданої вартості при дослідження агропродовольчих ланцюгів доцільно проводити на рівні кожного учасника (актора) необхідно 3 двох точок зору: по-перше, цей показник доцільно включити для проведення комплексного аналізу за оцінкою результативності та формування вартості, що дозволить впровадити вартісно-орієнтовані підходи до управління, що вимагає удосконалення та розробки нових форм фінансової звітності, які дозволили об'єктивно визначити показник доданої вартості; по-друге, суцільне визначення доданої вартості на рівні суб'єктів господарювання в якості показника звітності на підприємствах стало б потужним інформаційним забезпеченням розрахунків показників СНР на макрорівні.

Висновки. Підсумовуючи вищезазначене можна зробити висновок про те, що додана вартість $є$ однією із найбільш багатогранних наукових категорій, вивчення якої набуває важливого значення у рамках ланцюгового підходу та характеризує потенційну суспільну цінність виробленого продукту на етапі ії формування, а також ринкову цінність у грошовому еквіваленті на етапі ринкової актуалізації вартості. Обгрунтовано, що незважаючи на певну уніфікованість розглянутих підходів до 
визначення величини доданої вартості, у різних галузях господарювання мають місце специфічні, характерні конкретному роду діяльності аспекти, які в обов'язковому порядку необхідно враховувати при розрахунку величини доданої вартості.

Виявлено, що у світовій практиці розроблено інструментарій оцінки глобальних ланцюгів поставок, який дозволяє на основі системи даних Системи національних рахунків і таблиць «Затрати-Випуск» виділяти агреговані ланцюги доданої вартості та визначити роль та місце кожної країни як учасника міжнародного виробничого ланцюга у виробництві та споживанні доданої вартості. Основним показником оцінки результативності міжнародної торгівлі економіки $\epsilon$ показник «додана вартість національного походження в експорті», методика якого розроблена в рамках глобальної ініціативи ОЕСР та СОТ «Торгівля в доданій вартості». Використання цього методичного підходу дозволяє поділити величину ВВП на дві частини - вироблену в результаті експорті та вироблену для задоволення внутрішнього попиту, що дозволяє об'єктивно частку економіки конкретної країни у формуванні величини доданої вартості.

Доведено, що у системі національного рахівництва додана вартість використовується для розрахунку величини ВНП, який відображає лише капіталізовану економічною системою матеріальну частину продукування цього показника. 3 метою нівелювання розбіжностей у величині показника доданої вартості на мікро- та макрорівнях необхідно гармонізувати бухгалтерську звітність економічних суб'єктів до вимог СНР та передбачити виділення показника доданої вартості окремим рядком, у результаті чого з'явиться можливість оцінити внесок конкретного суб'єкта в загальній сумі валового внутрішнього продукту. Вважаємо, що розрахунок доданої вартості при дослідження агропродовольчих ланцюгів доцільно проводити на рівні кожного актора та в цілому, що дозволить оцінити результативність та внесок кожного учасника показника валового національного продукту країни.

1. Дж. М. Кейнс. Общая теория занятости, процента и денег. М.: Гелиос АРВ, 2011. 352 с.

2. Пономаренко, А. Н., Мурадов, К. Ю. Новая статистика движения добавленной стоимости в международной торговле.Экономический журнал ВШЭ. 2014. № 1. С. 43-79.

3. OECD-WTO (2018). Trade in Value Added (TiVA): Value added in gross exports by source country and source industry. OECD Statistics. URL: https://www.oecd.org/sti/ind/measuring-trade-in-valueadded.htm (дата звернення: 20.11.2020)

4. Measuring Trade in Value Added: An OECD-WTO joint initiative. ULR: https://www.wto.org/english/res_e/statis_e/miwi_e/tradedataday13_e/oecdjanv13_e.pdf_ (дата звернення: 2.11.2020)

5. TiVA 2015 indicators - definitions. Version 2, October 2015. - OECD (2015). ULR: https://www.oecd.org/sti/ind/tiva/TIVA_2015_Indicators_Definitions.pdf (дата звернення: 2.11.2020)

6. Концепція розвитку системи національних рахунків від 25 липня 2002 р. № 413-p. ULR: http://zakon0.rada.gov.ua/laws/show/413-2002-\%D1\%80 (дата звернення: 2.11.2020)

7. Методологічні положення 3 організації державногостатистичного спостереження «таблиця «витрати-випуск»: Наказ Державної служби статистики України 01 листопада 2018 р. № 236 (зі змінами, затвердженими наказом Державної служби статистики України від 11 березня 2020 р. № 101). ULR: http://www.ukrstat.gov.ua/norm_doc/2020/101/101.pdf (дата звернення: 2.11.2020)

8. Кравцова I. В. Методика дослідження глобальних ланцюгів створення вартості. Науковий вісник Міжнародного гуманітарного університету: зб. наук. праць. 2016. Вип. 16. С. 39-44.

9. Методологічні положення оновленої версії системи національних рахунків2008 року (наказ Державної служби статистики України від 17.12.2013№ 398). ULR: http://www.ukrstat.gov.ua (дата звернення: 2.11.2020)

References
1. Keynes, J. M. General theory of employment, interest and money. Moscow, Helios ARV, 2011.

2. Ponomarenko, A.N., and K. Yu.Muradov. "New statistics on the movement of value added in international trade.” HSE Economic Journal, no.1, 2014, pp. 43-79. 
3. OECD-WTO (2018). Trade in Value Added (TiVA): Value added in gross exports by source country and source industry. OECD Statistics, www.oecd.org/sti/ind/measuring-trade-in-value-added.htm. Accessed 2.11.2020.

4. "Measuring Trade in Value Added: An OECD-WTO joint initiative." WTO, https://www.wto.org/english/res_e/statis_e/miwi_e/tradedataday13_e/oecdjanv13_e.pdf. Accessed 2.11.2020.

5. TiVA 2015 indicators - definitions. Version 2, October 2015. OECD, www.oecd.org/sti/ind/tiva/TIVA_2015_Indicators_Definitions.pdf. Accessed 2.11.2020.

6. “The concept of development of the system of national accounts of July 25, 2002 № 413-r.” The Verkhovna Rada of Ukraine, zakon0.rada.gov.ua/laws/show/413-2002-\%D1\%80. Accessed 2.11.2020.

7. Methodological provisions on the organization of state statistical observation "cost-output table": Order of the State Statistics Service of Ukraine November dated 1, 2018 № 236. State Statistics Service of Ukraine, www.ukrstat.gov.ua/norm_doc/2020/101/101.pdf. Accessed 2.11.2020.

8. Kravtsova, I.V. Methods of research of global value chains. Scientific Bulletin of the International Humanities University, issue 16, 2016, pp. 39-44.

9. Methodological provisions of the updated version of the system of national accounts of 2008: Order of the State Statistics Service of Ukraine dated 17.12.2013№ 398). State Statistics Service of Ukraine, www.ukrstat.gov.ua. Accessd 2.11.2020. 